\title{
A VERTENTE TENSIVA DA SEMIÓTICA GREIMASIANA NO BRASIL: BREVE ESTUDO HISTORIOGRÁFICO
}

\author{
TENSIVE SEMIOTICS IN BRAZIL: \\ A SHORT HISTORIOGRAPHIC STUDY
}

\author{
Dayane Celestino de Almeida ${ }^{1}$ \\ USP - Universidade de São Paulo
}

\begin{abstract}
RESUMO: O trabalho que proponho pretende realizar uma breve historiografia da recepção da chamada "Semiótica Tensiva" - vertente da Semiótica Greimasiana - no Brasil, valendo-se de métodos e propostas interpretativas da Historiografia da Linguística, baseando-se em parâmetros externos e internos e utilizando categorias de análise tais como programas de investigação, grupos de especialidade e tipo de retórica.
\end{abstract}

PALAVRAS-CHAVE: Semiótica Greimasiana; Semiótica Tensiva; Historiografia da Linguística; Brasil.

ABSTRACT: The paper that I here propose aims to present a short historiographic study on the "Tensive Semiotics" - a strand of the French Semiotics - in Brazil, using methods and interpretative proposals from the Linguistics Historiography, based on external and internal parameters and applying analytic categories such as investigation programs, research groups and argumentation patterns.

KEYWORDS: French Semiotics; Tensive Semiotics; Linguistics Historiography; Brazil.

\section{Introdução}

Em razão da existência de diversas disciplinas que recebem atualmente o nome de "semiótica", devo, antes de mais nada, esclarecer que a Semiótica à qual me refiro neste trabalho é a chamada Semiótica "Greimasiana" - também conhecida como Semiótica Francesa ou Semiótica da Escola de Paris - que teve como fundador Algirdas Julien Greimas e cujo objeto é o sentido, nas suas mais variadas formas de manifestação discursiva.

Tendo surgido na década de 60, a Semiótica Francesa vem ganhando cada vez mais adeptos. No Brasil, os estudos nesta área começaram nos anos 70 e desde então cresceu consideravelmente o número de pesquisadores e grupos de pesquisa que se dedicam ao assunto. Barros (1999, p. 192) afirma:

A linha de investigação semiótica tem seus principais e mais antigos núcleos em São Paulo, na Universidade de São Paulo - USP, sobretudo na pós-graduação em Linguistica e na Escola de Comunicações e Artes - ECA,

\footnotetext{
${ }^{1}$ Este trabalho foi realizado com o apoio do CNPq - Conselho Nacional de Desenvolvimento Científico e Tecnológico.
} 
e na Universidade Estadual Paulista - UNESP, em Araraquara e em São José do Rio Preto. Nessas universidades formou-se a maioria dos pesquisadores em Semiótica no Brasil e desenvolveu-se grande parte dos projetos de pesquisa na área. Em 1973, constituiu-se, com pesquisadores dessas instituições, um Centro de Estudos Semióticos que teve papel inegável na formação de pesquisadores e na divulgação dessa linha de pesquisa. Há atualmente outros grupos que merecem destaque, na PUC-SP (com um Centro de Estudos Sociossemióticos muito ativo), nas universidades federais do Rio Grande do Sul - UFRGS, de Minas Gerais UFMG e Fluminense - UFF, na Universidade Estadual Paulista - UNESP, em Assis e na Universidade de Londrina - UEL.

De acordo com a mesma autora,

três direções têm sido empreendidas no Brasil: A primeira sobre a sintaxe e a semântica do discurso, com estudos que examinam principalmente as estratégias do discurso (...). A segunda direção congrega estudos que revêem a concepção e organização do nível fundamental dos discursos, a partir de estudos sobre figuratividade e a tensividade do esquema profundo. A terceira, diz respeito aos estudos de uma semiótica específica - discursos visuais, gustativos, poéticos, estéticos, da canção popular, da música, da pintura, do cinema [...].

É na segunda direção apontada por Barros que estão os estudos relacionados ao campo da Semiótica Francesa que tem sido chamado de "Semiótica Tensiva". O trabalho que proponho pretende realizar uma breve historiografia da recepção desta corrente da Semiótica Greimasiana no Brasil, valendo-se de métodos e propostas interpretativas da Historiografia da Linguistica, baseando-se em parâmetros externos e internos e utilizando categorias de análise tais como programas de investigação, grupos de especialidade e tipo de retórica.

$\mathrm{O}$ interesse em realizar esse trabalho nasceu, pois, sendo parte do Grupo de Estudos Semióticos (GES-USP) há alguns anos, tendo sido aluna de Iniciação Científica em Semiótica e sendo, atualmente, aluna da pós-graduação na mesma área, percebi que houve, nos últimos anos, considerável aumento do interesse pelas concepções da Semiótica Tensiva. Muitos dos trabalhos concluídos dentro dos últimos anos ou em andamento no presente momento utilizam - em maior ou menor grau - conceitos provenientes desta corrente. Além disso, a tradução de textos com esta visão tomou fôlego (explicitarei mais adiante quais foram estas traduções) evidenciando aumento de interesse pela teoria, por parte de novos pesquisadores. Dois fatos ocorridos no ano de 2008 foram decisivos para aguçar ainda mais a minha curiosidade: o primeiro foi o GT de Semiótica da ANPOLL (Associação Nacional de Pós-Graduação em Letras e Linguistica) ter escolhido, no XXIII Encontro Nacional, o tema "Rotina e Acontecimento" - tema dos mais atuais e importantes nos escritos de Claude Zilberberg, principal divulgador da teoria tensiva - como aquele a ser pesquisado no próximo biênio; o segundo foi o curso oferecido pelo próprio Claude Zilberberg, na Universidade de São Paulo, que contou, segundo sua comissão organizadora, com mais de 100 inscritos.

Ao realizar este estudo, pretendo responder a algumas questões:

1) A Semiótica Tensiva é considerada, pelos pesquisadores brasileiros, um novo paradigma de pesquisa? 2) Os pesquisadores que produzem trabalhados relacionados à Semiótica Tensiva formam um grupo de especialidade? 3) Qual o papel das lideranças intelectuais e organizacionais na divulgação e expansão da Semiótica Tensiva no Brasil? 4) 
Em que medida a adoção das concepções da Semiótica Tensiva ajudou os pesquisadores brasileiros a melhor abordar os seus objetos.

Em termos de organização, este trabalho está disposto da seguinte maneira: na parte 1, teço algumas considerações acerca da Historiografia Linguistica. Na parte 2, descrevo minhas opções metodológicas, tal como periodização e escolha dos materiais de análise. A terceira parte traz um breve panorama sobre a Semiótica Francesa, explicitando alguns de seus pressupostos e apresentando algumas fases de seu desenvolvimento desde seu surgimento até os dias atuais. Ainda nesta parte, falo do aparecimento da Semiótica Tensiva e procuro caracterizá-la. Por fim, na quarta parte faço a narrativa historiográfica da Semiótica Tensiva no Brasil, observando como se deu a sua recepção e os desenvolvimentos iniciais no âmbito nacional e o que foi percebido por alguns semioticistas brasileiros com relação a essa linha de pesquisa. Pretendo, ainda, identificar em que tipo de objetos semióticos se concentra a pesquisa tensiva e fazer uma breve análise quantitativa do crescimento da vertente no Brasil.

Tendo em vista que este é um trabalho preliminar, sei que não é possível cobrir todos os pontos relevantes e nem mesmo levantar todos os dados que seriam necessários para um estudo historiográfico mais amplo. Entretanto, espero que minha contribuição esteja no fato de abrir caminho para a reflexão sobre as pesquisas semióticas que se fazem no Brasil na atualidade e preparar o terreno para futuras pesquisas mais abrangentes, seja com relação à vertente tensiva, seja com relação a outras correntes ligadas ao projeto greimasiano.

\section{Observações acerca da Historiografia Linguistica}

A Historiografia caracteriza-se por ser um texto sobre a História. Em outras palavras, a História é o objeto da Historiografia, é a fonte em que o historiógrafo busca, seleciona os fatos relevantes para o seu estudo, hierarquizando-os. Altman (2003, p. 28) elenca as tarefas da atividade historiográfica:

A atividade historiográfica que ambiciona compreender os movimentos em história da ciência presume, inevitavelmente, uma atividade de seleção, ordenação, reconstrução e interpretação dos fatos relevantes para o quadro de reflexão que constrói o historiógrafo.

Para Sebeok (1975 apud KOERNER, 1996) a Historiografia da Linguistica é o "modo de escrever a história do estudo da linguagem baseado em princípios" e não “(meramente) registrar a história da pesquisa linguistica”. Swiggers (1990, p.21) define a Historiografia da Linguistica como a disciplina que descreve e explica como o conhecimento lingüístico foi obtido, formulado e divulgado, além de explicar como esse conhecimento se desenvolve no tempo.

A Historiografia considera fatores como agentes (quem), motivações/problemas e contexto em suas análises. Assim, não só a dimensão "interna", ou seja, a do desenvolvimento da disciplina, é considerada, mas também a sua dimensão "externa", isto é, a sua dimensão individual e social.

Em se tratando da dimensão interna de uma ciência ou disciplina relacionada às ciências da linguagem, vejamos o conceito de "programa de investigação", tal como proposto por Swiggers (1981 apud ALTMAN, 2003, p.40). Segundo o autor:

A program is a complex cognitive system which makes possible some particular operations and results, while excluding other possibilities. One program subsumes several theories which, despite technical and 
terminological differences, have the same concept of how the object of the discipline must be investigated.

Swiggers propõe, ainda, que, na História da Linguistica, do ponto de vista interno, haja quatro tipos principais de programas de investigação:

O programa de correspondência é aquele que agrega teorias cujo pressuposto é a linguagem como meio de expressão do pensamento, havendo correspondência entre linguagem, pensamento e realidade. Exemplos de lingüistas que trabalham ou trabalharam neste programa seriam Platão, Varrão, Guillaume, Chomsky, entre outros. O programa descritivista vê a língua como uma estrutura autônoma de dados formais a serem descritas. Estariam incluídos neste programa, por exemplo, os neogramáticos, os estruturalistas e os funcionalistas. A língua como fato social ou cultural é o ponto de vista do programa sociocultural. Estudos sobre variação lingüística e sobre o sentido como "determinado por um contexto pragmático mais amplo e por uma sociedade comunicativa" (ALTMAN, 2003, p.41) são parte deste programa. Por fim, Swiggers fala do programa de projeção: aquele que vê as línguas como conjuntos de fragmentos lógicos. Por este modelo, a Semiótica Greimasiana estaria ligada ao programa sociocultural.

No que diz respeito à dimensão social, um conceito importante seria de "grupo de especialidade", defendido por Murray (1994). O autor propõe estágios pelos quais grupos científicos passam em seu desenvolvimento. O primeiro destes estágios é chamado de "normal" (p.14) e nele há pouca interação entre os pesquisadores (normalmente poucos) que se dedicam a uma determinada proposta teórica. Conforme Batista (2007, p. 28), nesse estágio "é necessário que haja, ao menos, um trabalho [...] que represente uma peça importante para a futura estrutura que se vai erguer [...] caracterizando-se como programático". Tal trabalho faz emergir a figura de um (ou mais) líder intelectual e é esta liderança que permitirá a agregação de estudantes ou pesquisadores mais experientes em torno da nova proposta. O segundo estágio é o que Murray (p.16) chama de "cluster". Este estágio se configura quando cientistas às voltas com as mesmas questões tomam consciência de ser parte de um grupo. Mullins (1973, p.23 apud MURRAY, 1994, p.16) afirma:

A cluster generally includes three or more professionals who reinforce one another's interests and several graduate students [...]. Intellectually, such a group concentrates on the specific set of problems defined by the program statement. Usually, large quantities of research are generated.

Murray defende, ainda, que um cluster pode se tornar um grupo de elite ou um grupo revolucionário. Se um grupo é aceito por uma comunidade científica, integrando-se a ela, tendo a possibilidade de publicar livros e artigos nos periódicos da área ele será um grupo de elite. Ao contrário, se um grupo encontrar rejeição, tornar-se-á um grupo revolucionário. Os grupos de elite, que se percebem bem recebidos, sustentam uma retórica continuísta, ao passo que os revolucionários assumem uma retórica revolucionária.

O terceiro estágio de formação de grupos - chamado de estágio de especialidade (em inglês, specialty stage) - se dá quando um cluster se especializa e se transforma em um grupo institucionalizado. "A specialty is an 'institutionalized cluster' and may be a formal organization" (MURRAY, 1994, p. 17). Por fim, Murray propõe o estágio acadêmico, no qual um novo paradigma é definitivamente aceito e bem sucedido e as concepções do grupo convertem-se em uma disciplina.

Fatores sociais são importantes, uma vez que não é apenas uma boa ideia que determina a emergência de uma nova orientação teórica. Por exemplo, a liderança intelectual 
é um fator decisivo na determinação do sucesso de uma teoria. Outro fato decisivo é a existência de um local onde os pesquisadores possam se encontrar com certa freqüência para discussão de problemas. A possibilidade de auxílio de instituições reconhecidas, de financiamento das pesquisas, de divulgação de resultados também constitui fatores fundamentais para a expansão e sucesso de um novo grupo.

Assim, com um estudo historiográfico procuro mapear os principais movimentos que explicam a recepção e recente crescimento dos estudos em Semiótica Tensiva em nosso país.

\section{Opções metodológicas: periodização e materiais de análise}

Considerarei como horizonte de retrospecção para esta narrativa historiográfica o período que se estende de 1994 até 2008. A escolha do ano de 1994 se justifica, pois foi este o ano da publicação de Semiótica da Canção, de Luiz Tatit, considerado o marco inicial dos estudos tensivos no Brasil (entrarei em mais detalhes no capítulo 4).

Pode parecer ao leitor que o período selecionado seja muito curto e muito "novo" para ser historiografado. A esta possível indagação, respondo citando Altman (2001, p.4 apud BATISTA, 2007, p.65; grifo meu):

Os jovens pesquisadores do grupo de historiografia também precisam ser sensíveis à necessidade de buscar, de alguma maneira, $\underline{\text { o diálogo com } \mathrm{o}}$ lingüista do presente, e não perder de vista a perspectiva contemporânea do(s) objeto(s) da sua reflexão.

Os materiais selecionados para análise foram: Entrevista Estruturada, Depoimento, Artigos de Periódicos, Traduções, Teses e Dissertações.

O depoimento de que dispomos foi concedido em Dezembro de 2008, na Universidade de São Paulo, por Luiz Tatit - considerado por seus pares o principal divulgador das ideias zilberberguianas no Brasil.

O semioticista selecionado para a Entrevista Estruturada foi Ivã Carlos Lopes. Lopes concluiu seu doutorado em 1998 sob orientação de Luiz Tatit. Desde então, tem trabalhado constantemente com Semiótica Tensiva em seus escritos. Assim como Tatit, é professor do Departamento de Linguistica da Universidade de São Paulo e tem exercido importante papel de líder intelectual e organizacional no Grupo de Estudos Semióticos da USP.

Tanto na escolha de Tatit quanto na de Lopes considerei o fato de que ambos, comparados com outros semioticistas brasileiros, têm dedicado uma maior quantidade de reflexões aos estudos tensivos, além de terem traduzido - ao lado de Waldir Beividas muitos dos textos de Claude Zilberberg.

Abaixo, reproduzo as perguntas que preparei para a entrevista estruturada:

1) Em sua opinião, qual é o marco introdutório da Semiótica Tensiva no Brasil? Quais as conseqüências desse momento para a implantação e desenvolvimento das pesquisas?

2) Em sua opinião, qual é a visão que os pesquisadores estrangeiros (principalmente de Claude Zilberberg) têm das pesquisas em Semiótica Tensiva realizadas no Brasil? 
3) Você acredita que os pesquisadores envolvidos com a Semiótica Tensiva no Brasil caminham em direção à formação de um grupo de especialidade diferente do que é o grupo de Semiótica Greimasiana?

4) Quais foram e quais são os principais pesquisadores e grupos de pesquisa envolvidos com as questões do projeto tensivo? Pode-se falar em uma liderança intelectual? Quem a exerce?

5) Qual é o papel do intercâmbio com centros internacionais de pesquisa no desenvolvimento da Semiótica Tensiva no Brasil?

6) Você acha que no Brasil as pesquisas na área de Semiótica Tensiva estão alinhadas com o que ocorre na França ou há uma defasagem com relação ao centro produtor?

7) Como você enxerga a Semiótica Tensiva dentro do Projeto da Semiótica da Escola de Paris? É uma outra teoria? Um complemento? Um novo paradigma?

Os artigos de periódicos foram selecionados em dois periódicos exclusivos de Semiótica que, ao que parece, mais divulgam artigos específicos sobre Semiótica Greimasiana. Nestes periódicos, procurei os artigos que de alguma forma fizeram uso de conceitos provenientes do desenvolvimento tensivo ou o mencionaram. Os periódicos em questão foram os Cadernos CASA (Cadernos de Semiótica Aplicada) e a Revista ESSE (Estudos Semióticos), criados respectivamente em 2003 e 2005. Ambos os periódicos possuem ISSN, corpo e política editorial. Os números verificados foram os que saíram desde a criação dos periódicos até a sua última edição. A seguir, apresento um quadro-resumo dos artigos selecionados:

Quadro I: Quadro-resumo dos artigos selecionados

\begin{tabular}{|c|c|c|c|l|}
\hline PERIÓDICO & ANO & VOL./NR. & AUTOR & TÍTULO \\
\hline CASA & 2003 & $1 / 1$ & Ana Cristina Fricke Matte & $\begin{array}{l}\text { "Porque Sim não é resposta! } \\
\text { prazer utilitário vs. prazer } \\
\text { criativo" }\end{array}$ \\
\hline CASA & 2003 & $1 / 2$ & $\begin{array}{c}\text { Maria José Guerra } \\
\text { Figueiredo Garcia }\end{array}$ & $\begin{array}{l}\text { "Em busca do conceito de } \\
\text { valor" }\end{array}$ \\
\hline CASA & 2004 & $2 / 1$ & Peter Dietrich & $\begin{array}{l}\text { "Viola, meu bem: o arranjo na } \\
\text { construção do sentido da } \\
\text { canção" }\end{array}$ \\
\hline CASA & 2004 & $2 / 2$ & $\begin{array}{c}\text { Sylvio Frederico Dias } \\
\text { Martins }\end{array}$ & $\begin{array}{l}\text { "Análise semiótica da canção } \\
\text { "Hino de Duran", de Chico } \\
\text { Buarque de Hollanda" }\end{array}$ \\
\hline CASA & 2004 & $2 / 2$ & $\begin{array}{c}\text { Antonio Vicente } \\
\text { Pietroforte }\end{array}$ & $\begin{array}{l}\text { "Uma imagem da música: } \\
\text { análise semiótica de uma capa } \\
\text { de disco" }\end{array}$ \\
\hline
\end{tabular}


CASA, Vol.7 n.2, dezembro de 2009

\begin{tabular}{|c|c|c|c|c|}
\hline CASA & 2004 & $2 / 2$ & Arnaldo Cortina & "Duas leituras da paixão" \\
\hline CASA & 2005 & $3 / 1$ & Nilton Hernandes & $\begin{array}{l}\text { "A Trilogia Matrix: Estratégias } \\
\text { de Enunciação Sincrética em } \\
\text { Textos Cinematográficos" }\end{array}$ \\
\hline CASA & 2005 & $3 / 2$ & Silvia Maria de Sousa & $\begin{array}{l}\text { "Luz, câmera, } \\
\text { moviment(ação). Estratégias } \\
\text { enunciativas de construção do } \\
\text { sincretismo no Programa } \\
\text { Silvio Santos" }\end{array}$ \\
\hline CASA & 2006 & $4 / 1$ & $\begin{array}{c}\text { José Aníbal Ortiz } \\
\text { Manrique }\end{array}$ & $\begin{array}{l}\text { "La crisis pasional en el rito de } \\
\text { entierro desarrollado por un } \\
\text { grupo de jóvenes de la } \\
\text { periferia de Bucaramanga" }\end{array}$ \\
\hline CASA & 2006 & $4 / 2$ & Ivã Carlos Lopes & $\begin{array}{l}\text { "Noção de "Profundidade" na } \\
\text { Semiótica" }\end{array}$ \\
\hline CASA & 2006 & $4 / 2$ & $\begin{array}{c}\text { João Marcos Mateus } \\
\text { Kogawa }\end{array}$ & $\begin{array}{l}\text { "Uma leitura sobre a } \\
\text { configuração passional em } \\
\text { 'Carta de herdade'" }\end{array}$ \\
\hline CASA & 2006 & $4 / 2$ & Luciane de Paula & $\begin{array}{l}\text { "O suingue funk da canção } \\
\text { SLA" }\end{array}$ \\
\hline CASA & 2007 & $5 / 2$ & José Luiz Fiorin & $\begin{array}{l}\text { "Paixões, afetos, emoções e } \\
\text { sentimentos" }\end{array}$ \\
\hline CASA & 2007 & $5 / 2$ & $\begin{array}{l}\text { Dayane Celestino de } \\
\text { Almeida }\end{array}$ & $\begin{array}{l}\text { Análise Semiótica do Poema } \\
\text { 'Os Sapos', de Manuel } \\
\text { Bandeira }\end{array}$ \\
\hline CASA & 2007 & $5 / 2$ & Peter Dietrich & $\begin{array}{l}\text { "Discurso musical e discurso } \\
\text { de produção musical" }\end{array}$ \\
\hline CASA & 2008 & $6 / 1$ & Jacques Fontanille & $\begin{array}{l}\text { "Semiótica do Discurso: } \\
\text { balanços e perspectivas" }\end{array}$ \\
\hline CASA & 2008 & $6 / 1$ & Celso Donizete Cruz & $\begin{array}{l}\text { "Tristeza do Jeca, canto do } \\
\text { caipira" }\end{array}$ \\
\hline CASA & 2008 & $6 / 1$ & $\begin{array}{c}\text { Márcia Maria Sant'Ana } \\
\text { Joé }\end{array}$ & $\begin{array}{l}\text { "O corpo nu: Ritmo nos } \\
\text { poemas 'Leda' e' As Três } \\
\text { graças', de Carlos Drummond } \\
\text { de Andrade, e nas pinturas de } \\
\text { Da Vinci e Rubens" }\end{array}$ \\
\hline CASA & 2008 & $6 / 1$ & Eliane Soares de Lima & $\begin{array}{l}\text { "A personagem narrativa e as } \\
\text { paixões: A construção da } \\
\text { subjetividade" }\end{array}$ \\
\hline ESSE & 2006 & 2 & Dilson Ferreira da Cruz & $\begin{array}{l}\text { "A retórica de Tapiiraiauara ou } \\
\text { considerações } \\
\text { para uma análise tensiva da } \\
\text { alusão" }\end{array}$ \\
\hline
\end{tabular}


CASA, Vol.7 n.2, dezembro de 2009

\begin{tabular}{|c|c|c|c|c|}
\hline ESSE & 2006 & 2 & Maria Lúcia Vissoto & $\begin{array}{l}\text { "Práxis enunciativa no } \\
\text { telejornal: } \\
\text { tensividade em notícia" }\end{array}$ \\
\hline ESSE & 2006 & 2 & $\begin{array}{c}\text { Tâmara Cintra e Tatiana } \\
\text { Brandão }\end{array}$ & $\begin{array}{l}\text { "Sailor moon: uma análise } \\
\text { semiótica de manga" }\end{array}$ \\
\hline ESSE & 2006 & 2 & José Ferreira de Lucena Jr. & $\begin{array}{l}\text { "Análise semiótica do poema } \\
\text { 'Vulgívaga' de } \\
\text { Manuel Bandeira" }\end{array}$ \\
\hline ESSE & 2007 & 3 & $\begin{array}{l}\text { Dayane Celestino de } \\
\text { Almeida }\end{array}$ & $\begin{array}{l}\text { "Análise semiótica da } \\
\text { 'Desencanto', de Manuel } \\
\text { Bandeira" }\end{array}$ \\
\hline ESSE & 2007 & 3 & $\begin{array}{l}\text { Isabel Gueselha de } \\
\text { Almeida }\end{array}$ & $\begin{array}{l}\text { "A intersecção de gêneros } \\
\text { discursivos na crônica } \\
\text { de Fernando Bonassi" }\end{array}$ \\
\hline ESSE & 2007 & 3 & Danilo Chiovatto Serpa & $\begin{array}{l}\text { "Mecanismos de construção da } \\
\text { polifonia na obra } \\
\text { O jogador de Dostoiévski" }\end{array}$ \\
\hline ESSE & 2007 & 3 & Bruna Paola Zerbinatti & $\begin{array}{l}\text { "'O mínimo do máximo': } \\
\text { antítese e estese" }\end{array}$ \\
\hline ESSE & 2008 & 4 & $\begin{array}{l}\text { Dayane Celestino de } \\
\text { Almeida }\end{array}$ & $\begin{array}{l}\text { "A valoração em metapoemas } \\
\text { de Manuel Bandeira: } \\
\text { universal ou absoluto?" }\end{array}$ \\
\hline ESSE & 2008 & 4 & $\begin{array}{c}\text { Elaine Aparecida Souto } \\
\text { Antunes }\end{array}$ & $\begin{array}{l}\text { "As relações entre quatro } \\
\text { sujeitos - Téo, Fernanda, } \\
\text { Salete e Lucas - na telenovela } \\
\text { Mulheres apaixonadas" }\end{array}$ \\
\hline ESSE & 2008 & 4 & Fabiane Borsato & $\begin{array}{l}\text { "A dimensão figurativa em } \\
\text { poemas de A educação pela } \\
\text { pedra, de João Cabral de Melo } \\
\text { Neto" }\end{array}$ \\
\hline ESSE & 2008 & 4 & Dilson Ferreira da Cruz & $\begin{array}{l}\text { "Algumas considerações sobre } \\
\text { o crer e o saber" }\end{array}$ \\
\hline ESSE & 2008 & 4 & Francisco Merçon & $\begin{array}{l}\text { "Considerações acerca da } \\
\text { figuratividade e da percepção" }\end{array}$ \\
\hline ESSE & 2008 & 4 & Camila Ribeiro & $\begin{array}{l}\text { "A missividade em Ciao } \\
\text { cadáver, de Delmo } \\
\text { Montenegro }\end{array}$ \\
\hline ESSE & 2008 & 4 & Bruna Paola Zerbinatti & $\begin{array}{l}\text { "Limiares, limites e } \\
\text { modalidades em 'Mais ou } \\
\text { menos em ponto'", de Paulo } \\
\text { Leminski }\end{array}$ \\
\hline ESSE & 2008 & 4 & $\begin{array}{l}\text { Márcia Maria Sant'Ana } \\
\text { Joé }\end{array}$ & $\begin{array}{l}\text { "Escrituras de Drummond: } \\
\text { Arte em exposição(Questões de } \\
\text { iconicidade e abstração) }\end{array}$ \\
\hline
\end{tabular}


CASA, Vol.7 n.2, dezembro de 2009

\begin{tabular}{|l|l|l|l|l|} 
ESSE & 2008 & 4 & Natália Guirado & $\begin{array}{l}\text { "Análise semiótica do poema: } \\
\text { En la humedad cifrada'", de } \\
\text { Coral Bracho }\end{array}$ \\
\hline
\end{tabular}

Outra fonte para este trabalho foram as Traduções de textos/livros sobre os aspectos tensivos. $\mathrm{O}$ quadro a seguir mostra quais foram estas obras:

Quadro II: Traduções de textos de orientação tensiva

\begin{tabular}{|c|c|c|c|c|c|c|}
\hline $\begin{array}{l}\text { ANO } \\
\text { DO } \\
\text { ORIGI- } \\
\text { NAL } \\
\end{array}$ & AUTOR & $\begin{array}{l}\text { TÍTULO DO } \\
\text { ORIGINAL }\end{array}$ & $\begin{array}{c}\text { ANO DA } \\
\text { TRADU- } \\
\text { ÇÃO }\end{array}$ & $\begin{array}{c}\text { TITULO EM } \\
\text { PORTUGUÊS }\end{array}$ & TRADUTOR(ES) & TIPO \\
\hline 1998 & $\begin{array}{c}\text { Claude } \\
\text { Zilberberg; } \\
\text { Jacques } \\
\text { Fontanille }\end{array}$ & $\begin{array}{c}\text { Tension et } \\
\text { signification }\end{array}$ & 2001 & $\begin{array}{c}\text { Tensão e } \\
\text { Significação }\end{array}$ & $\begin{array}{l}\text { Luiz Tatit, Ivã } \\
\text { Lopes e Waldir } \\
\text { Beividas }\end{array}$ & Livro \\
\hline 2001 & $\begin{array}{l}\text { Claude } \\
\text { Zilberberg }\end{array}$ & $\begin{array}{l}\text { Les contraintes } \\
\text { sémiotiques du } \\
\text { métissage }\end{array}$ & 2004 & $\begin{array}{c}\text { As condições } \\
\text { semióticas da } \\
\text { mestiçagem }\end{array}$ & $\begin{array}{l}\text { Luiz Tatit, Ivã } \\
\text { Lopes }\end{array}$ & $\begin{array}{l}\text { Capítulo de } \\
\text { Livro }\end{array}$ \\
\hline 2002 & $\begin{array}{c}\text { Claude } \\
\text { Zilberberg }\end{array}$ & $\begin{array}{c}\text { Précis de } \\
\text { grammaire } \\
\text { tensive }\end{array}$ & 2006 & $\begin{array}{l}\text { "Síntese da } \\
\text { Gramática } \\
\text { Tensiva" }\end{array}$ & $\begin{array}{l}\text { Luiz Tatit e Ivã } \\
\text { Lopes }\end{array}$ & $\begin{array}{c}\text { Artigo na } \\
\text { Revista } \\
\text { Significação }\end{array}$ \\
\hline 1988 & $\begin{array}{c}\text { Claude } \\
\text { Zilberberg }\end{array}$ & $\begin{array}{c}\text { Raison et } \\
\text { poétique du sens }\end{array}$ & 2006 & $\begin{array}{c}\text { Razão e Poética } \\
\text { do Sentido }\end{array}$ & $\begin{array}{l}\text { Luiz Tatit, Ivã } \\
\text { Lopes e Waldir } \\
\text { Beividas }\end{array}$ & Livro \\
\hline 2006 & $\begin{array}{l}\text { Claude } \\
\text { Zilberberg }\end{array}$ & $\begin{array}{l}\text { Pour saluer } \\
\text { l'évenement }\end{array}$ & 2007 & $\begin{array}{l}\text { Louvando o } \\
\text { acontecimento }\end{array}$ & $\begin{array}{c}\text { Maria Lucia } \\
\text { Vissotto Paiva } \\
\text { Diniz }\end{array}$ & $\begin{array}{l}\text { Artigo na } \\
\text { Revista } \\
\text { Galáxia }\end{array}$ \\
\hline 2006 & $\begin{array}{l}\text { Claude } \\
\text { Zilberberg }\end{array}$ & $\begin{array}{l}\text { Eléments de } \\
\text { grammaire } \\
\text { tensive }\end{array}$ & $\begin{array}{c}\mathrm{em} \\
\text { andamento }\end{array}$ & a definir & $\begin{array}{c}\text { Luiz Tatit, Ivã } \\
\text { Lopes e Waldir } \\
\text { Beividas }\end{array}$ & Livro \\
\hline
\end{tabular}

Como as pesquisas na pós-graduação são decisivas para a expansão e continuidade de uma determinada linha de pesquisa, não poderia deixar de considerá-las neste estudo. O quadro a seguir mostra as teses de Mestrado e as dissertações de Doutorado realizadas com orientação principalmente tensiva desde o ano de 1994, na Universidade de São Paulo. Escolhi centrar a pesquisa nesta Universidade, num primeiro momento, por ser nela que se encontra o maior número de pesquisadores desta área, bem como os professores que indiquei anteriormente como líderes. A busca pelas outras universidades que mantém grupos na área de Semiótica Greimasiana será efetuada posteriormente, em outro trabalho. Abaixo, os quadros que apresentam as Dissertações de Mestrado e as teses de Doutorado de que falei: 
CASA, Vol.7 n.2, dezembro de 2009

Quadro III: Dissertações de Mestrado da USP que apresentam (em maior ou menor grau) um viés tensivo:

\begin{tabular}{|c|c|c|c|c|}
\hline ANO & AUTOR & TÍTULO & ORIENTADOR & LOCAL \\
\hline 1997 & $\begin{array}{l}\text { Monteiro, Ricardo } \\
\text { Nogueira de Castro }\end{array}$ & $\begin{array}{c}\text { Análise do discurso musical : } \\
\text { uma abordagem semiótica }\end{array}$ & Luiz Tatit & USP \\
\hline 2008 & $\begin{array}{l}\text { Jóe, Márcia Maria } \\
\text { Sant Ana }\end{array}$ & $\begin{array}{l}\text { Escrituras de Drummond-arte } \\
\text { em exposição : uma leitura } \\
\text { semiótica de poemas e pinturas }\end{array}$ & Ivã Carlos Lopes & USP \\
\hline 1998 & $\begin{array}{l}\text { Marrafão, Terezinha } \\
\text { de Jesus Dutra }\end{array}$ & $\begin{array}{c}\text { Elementos para uma análise } \\
\text { semiótica da seqüêencia inicial } \\
\text { do filme nostalgia de Andrei } \\
\text { Tarkovski }\end{array}$ & $\begin{array}{l}\text { Irenilde Pereira } \\
\text { Santos }\end{array}$ & USP \\
\hline 1999 & $\begin{array}{l}\text { Oliveira, Sérgio } \\
\text { Fernando } \\
\text { Campanella de }\end{array}$ & $\begin{array}{l}\text { Dicção dos intérpretes na } \\
\text { canção popular: uma } \\
\text { abordagem semiótica }\end{array}$ & Luiz Tatit & USP \\
\hline 2002 & $\begin{array}{l}\text { Coelho, Márcio Luiz } \\
\text { Gusmão }\end{array}$ & $\begin{array}{c}\text { Elementos para a análise } \\
\text { semiótica do arranjo na canção } \\
\text { popular brasileira }\end{array}$ & Luiz Tatit & USP \\
\hline 2003 & Dietrich, Peter & $\begin{array}{c}\text { Araçá azul : uma análise } \\
\text { semiótica }\end{array}$ & Luiz Tatit & USP \\
\hline 2003 & $\begin{array}{l}\text { Motta, Kary } \\
\text { Alessandra }\end{array}$ & $\begin{array}{c}\text { Elementos narrativos e tensivos } \\
\text { para abordagem da apreensão } \\
\text { estética }\end{array}$ & Luiz Tatit & USP \\
\hline 2006 & $\begin{array}{l}\text { Merçon, Francisco } \\
\text { Elias Simão }\end{array}$ & $\begin{array}{l}\text { Uma leitura analítica da novela } \\
\text { a metamorfose, de Franz Kafka }\end{array}$ & Luiz Tatit & USP \\
\hline
\end{tabular}


CASA, Vol.7 n.2, dezembro de 2009

Quadro IV: Teses de Doutorado da USP que apresentam (em maior ou menor grau) um viés tensivo:

\begin{tabular}{|c|c|c|c|c|}
\hline ANO & AUTOR & TÍTULO & ORIENTADOR & LOCAL \\
\hline 1997 & $\begin{array}{c}\text { Lopes, Flor Marlene } \\
\text { Enríquez }\end{array}$ & $\begin{array}{c}\text { Dinâmica da imagem fixa: o } \\
\text { estatuto do ritmo na pintura e } \\
\text { na fotografia }\end{array}$ & Luiz Tatit & USP \\
\hline 1998 & Lopes, Ivã Carlos & $\begin{array}{c}\text { Morfologias do Tempo : para } \\
\text { uma semiótica do que (se) } \\
\text { passa }\end{array}$ & Luiz Tatit & USP \\
\hline 1999 & $\begin{array}{l}\text { Garcia, Maria José } \\
\text { Guerra de } \\
\text { Figueiredo }\end{array}$ & $\begin{array}{c}\text { Em busca do conceito de valor: } \\
\text { uma abordagem } \\
\text { semiolinguistica }\end{array}$ & $\begin{array}{c}\text { Irenilde Pereira dos } \\
\text { Santos }\end{array}$ & USP \\
\hline 2002 & Farias, Iara Rosa & $\begin{array}{l}\text { Das figuras do mundo às } \\
\text { figuras do discurso : uma visão } \\
\text { semiótica da percepção }\end{array}$ & Luiz Tatit & USP \\
\hline 2002 & $\begin{array}{c}\text { Matte, Ana Cristina } \\
\text { Fricke }\end{array}$ & $\begin{array}{c}\text { Vozes e canções infantis } \\
\text { brasileiras }\end{array}$ & Luiz Tatit & USP \\
\hline 2002 & $\begin{array}{l}\text { Monteiro, Ricardo } \\
\text { Nogueira de Castro }\end{array}$ & $\begin{array}{c}\text { O sentido na música: } \\
\text { semiotização de estruturas } \\
\text { paradigmáticas e sintagmáticas } \\
\text { na geração de sentido musical }\end{array}$ & Luiz Tatit & USP \\
\hline 2005 & $\begin{array}{l}\text { Mancini, Renata } \\
\text { Ciampone }\end{array}$ & $\begin{array}{l}\text { Dinamização nos níveis do } \\
\text { percurso gerativo : canção e } \\
\text { literatura contemporânea }\end{array}$ & Luiz Tatit & USP \\
\hline 2007 & $\begin{array}{l}\text { Coelho, Márcio } \\
\text { Luiz Gusmão }\end{array}$ & $\begin{array}{l}\text { O arranjo como elemento } \\
\text { orgânico ligado à canção } \\
\text { popular brasileira }\end{array}$ & Luiz Tatit & USP \\
\hline
\end{tabular}

A análise do material aqui apresentado será efetuada mais adiante, na quarta parte. Os parâmetros a serem seguidos serão tanto relacionados à dimensão interna (conteúdo dos trabalhos selecionados e seu objeto de aplicação) quanto externa (situação de produção, autores, instituição, posição acadêmica ${ }^{2}$ ).

\footnotetext{
${ }^{2}$ Para maior esclarecimento sobre os parâmetros citados, ver ALTMAN (2003, p.51-55).
} 


\section{A Semiótica Greimasiana e a abordagem tensiva}

Herdeira da linguistica saussuriana, a Semiótica de Greimas tem por objeto, como já foi dito, o sentido. Ela se destaca por ser uma teoria da significação que busca desvendar os mecanismos de construção (ou geração) e apreensão do sentido nos diversos tipos de texto, postulando que os discursos são redes de relações e que a partir destas o sentido é gerado. Ou seja, o sentido está, não no signo a priori, mas nas relações que um signo estabelece com o outro dentro de cada texto. Além de ser uma teoria da significação, a Semiótica é também uma metodologia de análise de textos, entendo como textos não apenas as manifestações verbais, mas também aquelas que são expressas por outras linguagens.

Outros estudos lingüísticos que estão em suas bases são aqueles desenvolvidos pelo linguista dinamarquês Louis Hjelmslev e pelo Círculo Lingüístico de Praga (1926), com destaque para Roman Jakobson e Nikolai Trubetzkoi. Encontram-se, ainda, estudos antropológicos em suas fontes, principalmente os de Vladimir Propp e Lévi-Strauss. Muito importante foi também a influência dos estudos da fenomenologia voltados à percepção, realizados por Merleau-Ponty, sendo a principal obra a Fenomenologia da Percepção, de 1945.

A Semiótica tem como princípio o estudo do texto em si, ou seja, de maneira contrária a outras disciplinas de análise do discurso ou até mesmo ligadas à teoria literária, que têm como fio condutor uma investigação cujo ponto de partida é o exame "externo" do texto, ou "de fora para dentro", ela traça um percurso inverso: a Semiótica examina o texto "de dentro para fora", esforçando-se por construir, antes de tudo, uma escrupulosa descrição "interna" do texto, para, só então, ir em busca das suas conexões intertextuais ou contextuais. Assim, a Semiótica considera que o texto é um todo de significação que "produz em si mesmo as condições contextuais de sua leitura" (BERTRAND, 2003, p. 23). Em termos de programas de investigação (SWIGGERS) a semiótica seria um programa sociocultural.

Preocupada inicialmente com o estudo do plano do conteúdo (HJELMSLEV, 1975), a Semiótica propõe uma análise na forma de um "percurso gerativo do sentido", que vai desde as estruturas mais abstratas dos textos (pressupostas) até as mais concretas (pressuponentes). O texto seria, então, uma superposição de níveis diferentes, do mais simples ao mais complexo. "Gerativo" aqui se opõe então a "genético"; o que importa é o modo de produção de sentido e não a gênese do texto. O que está por trás de todo o percurso gerativo do sentido é a noção de uma gramática do texto. São três as etapas do percurso gerativo do sentido (cada uma com uma sintaxe e uma semântica), que resumo a seguir:

1) Nível fundamental: nível mais abstrato e que apresenta uma oposição semântica mínima que permeará todo o texto e estará na base de sua construção; quadrado semiótico;

2) Nível narrativo: organização narrativa que está "por trás" dos textos; costuma ser formulada em termos de transformações, envolvendo o ponto de vista de um "sujeito" que está em busca de um "objeto"; estruturas modais. Este nível é concebido pelo percurso: manipulação - competencialização ação - sanção;

3) Nível discursivo: o revestimento concreto dos níveis anteriores mais abstratos, levando-se em conta os graus de figuratividade dos conteúdos propostos, bem como as múltiplas estratégias de que se vale o enunciador para engendrar efeitos de proximidade ou distância enunciativa. Temas e figuras; Instauração de espaço, tempo, atores. 
A história da Semiótica Greimasiana pode ser dividida em 5 fases, a ver:

- Primeira fase: inicia-se com a publicação de Semântica Estrutural, de Greimas, em 1966. Esta obra é vista como o "discurso fundador" da disciplina, onde há o estabelecimento dos principais pressupostos. Nesta primeira fase, a teoria semiótica é basicamente uma teoria da ação, centrada principalmente nos estudos do nível narrativo. Outra obra muito importante desta primeira fase é o livro Sobre o Sentido (GREIMAS, 1970).

- Segunda fase: marcada pelos estudos das modalidades; aqui o foco muda da ação para a modalização e se procura responder à seguinte pergunta: por que o sujeito age? Nesta fase, ganham força os estudos sobre competência modal e tipologia dos sujeitos agentes. As "obras-chave" desta etapa são: Pour une théorie des modalités (Greimas, 1976) e Dicionário de Semiótica (GREIMAS; COURTÉS, 1979).

- Terceira fase: iniciam-se as investigações sobre as modalizações do ser; até a fase anterior, as atenções estavam voltadas ao fazer. Tal fase foi fundamental para a guinada dos estudos semióticos da Escola de Paris em direção à investigação do sensível e abordagem da afetividade. Em termos de publicações, destaco o livro Du Sens II (GREIMAS, 1983).

- Quarta fase: ligada ao estudo Semiótica das Paixões, que ganharam força a partir de 1983, com a publicação do livro Du Sens II, que trazia o estudo pioneiro "De la modalisation de l'être". O verdadeiro boom dos estudos sobre as paixões ocorreu em 1991, com a publicação de Semiótica das Paixões, de J. Fontanille e A. J. Greimas.

- Quinta fase: caracterizada pela proliferação de diversas vertentes teóricas, dentre elas a chamada "Semiótica Tensiva", objeto de nosso trabalho.

Tendo brevemente exposto os principais postulados da Semiótica Francesa, cabe entrarmos, enfim, no assunto mesmo deste trabalho, isto é, a Semiótica Tensiva. Esse novo modo de analisar a construção do sentido nasceu da necessidade de preencher uma lacuna existente no modelo semiótico estrutural. Luiz Tatit, na orelha da tradução brasileira de Razão e Poética do Sentido (ZILBERBERG, 2006a) assevera que a grande questão que se colocava era "Como abordar os conteúdos sensíveis ao lado dos conteúdos inteligíveis já então previstos pelo modelo descritivo de Algirdas Julien Greimas?". Enquanto o último estava calcado em análises do discreto e binário, com atenção voltada para a narratividade (o fazer) a abordagem tensiva passa a considerar em primeiro plano o contínuo, o dinâmico, o gradual e centra seus estudos na primazia do ser, possibilitando o estudo de fenômenos discursivos que não podiam ser analisados anteriormente. Há um enfoque no nível profundo e ocorre uma temporalização do modelo que, antes, considerava apenas o tempo no nível discursivo. Ademais, cabe destacar que o modelo greimasiano diz respeito ao plano do conteúdo, ao passo que a orientação tensiva incorpora estudos do plano da expressão.

A lacuna de que falei anteriormente pode ser considerada uma anomalia, nos termos de Kuhn (2007 [1962], p.83). Segundo o autor, uma anomalia é "um fenômeno para o qual o paradigma não prepara o investigador". De fato, o modelo desenvolvido pela Semiótica Francesa nos anos 60 e 70 não previa incursões no universo do sensível e não considerava os fenômenos contínuos, além de nunca ter desenvolvido satisfatoriamente um modelo para estudo do plano da expressão. No intuito de eliminar as anomalias, surgem diversas linhas de investigação na Semiótica da Escola de Paris, dentre as quais, a Semiótica Tensiva. Ribeiro (2008), resume as principais contribuições destes estudos: 
A ótica tensiva parece ter substituído uma semiótica das oposições (de Greimas), por uma semiótica dos intervalos, trazendo não apenas configuração mais dinâmica para o modelo semiótico como também preenchendo a maioria das lacunas deixadas pelo percurso gerativo greimasiano. O conceito de tensividade consegue tratar com coerência as questões relativas às paixões, ao sensível, à percepção e ainda une, em um só modelo, resoluções que são comuns aos dois planos da linguagem.

Outro depoimento que nos indica a importância de haver uma solução para os problemas do contínuo é aquele concedido pelo semioticista José Luiz Fiorin à Cristina Sampaio (2008) em entrevista publicada na Revista Eutomia, da Universidade Federal:

Como o primeiro estruturalismo se funda no descontínuo, ele trabalhou mal com fenômenos contínuos, como, por exemplo, a entoação. Exemplifiquemos uma questão do contínuo no texto: o ritmo do texto. Por que um texto parece apressado ou parece lento? Esse é um problema do contínuo, dentre dezenas, centenas de problemas do contínuo que existem.

Segundo o modelo de Kuhn, a acumulação das referidas anomalias pode por em cheque o paradigma existente, fazendo emergir um segundo paradigma, nem melhor, nem pior que o anterior, mas sim disposto a resolver problemas diferentes. O modelo de Kuhn prevê que uma nova teoria nunca é apenas um incremento de uma anterior: "uma nova teoria, por mais particular que seja seu âmbito de aplicação, nunca ou quase nunca é um mero incremento ao que já é conhecido" (2007, p. 26). Isto porque, se despontaram outros problemas a resolver, é porque mudou a maneira de olhar o objeto em questão e, se o ponto de vista determina o objeto - como afirmava Sausurre (CLG, 2002 [1916], p.15) - o próprio objeto não é mais o mesmo da reflexão anterior, emergindo um novo paradigma. Interessante é verificar que embora o modelo de Kuhn proponha esta ruptura entre um paradigma " 1 " e um paradigma " 2 ", os pesquisadores envolvidos com a Semiótica Tensiva insistem em dizer que não foi criado um novo paradigma. Por exemplo, em Tensão \& Significação (2001, p.9), Jacques Fontanille e Claude Zilberberg afirmam, ao se referir ao programa tensivo, que quando um ponto de vista compreende

a possibilidade de se pôr em perspectiva entre os outros pontos de vista e as outras coerências possíveis, então é uma outra maneira de fazer semiótica que se desenha, mais do que um outro 'paradigma'" (grifo nosso).

Na mesma obra, os autores declaram, ainda, que "a semiótica dos anos 90 não é nem exatamente a mesma, nem completamente outra, quando comparada à dos anos 70". Percebe-se, portanto, que os principais fundadores das ideias que norteiam esse novo campo de investigação assumem uma retórica de continuidade com a tradição que o precede. Em termos de como os semioticistas que praticam a tensiva enxergam este novo modelo, cito Lopes (Depoimento Pessoal, 2009):

A semiótica tensiva é filha da semiótica de A. J. Greimas. Não pode ser vista como um novo paradigma, mesmo porque o caminhar histórico das Humanidades, diferentemente do que ocorre nas ciências "duras", não é kuhniano [...]. 
O próprio Zilberberg (2008) disse, em entrevista a alunos da Universidade de São Paulo $^{3}$, que não considera ter inaugurado um novo paradigma.

Sendo assim, para explicar o que ocorre no caso do ponto de vista tensivo em relação à Semiótica de Greimas, recorro ao modelo proposto por Imre Lakatos (1979), sobre programas de investigação científica (noção análoga à de paradigma, em Kuhn) que continuam um determinado núcleo de conceitos, objetivos e métodos pertencentes a um certo programa de pesquisa. Tais programas de investigação seriam os responsáveis por "possíveis alterações, vistas como periféricas" (BATISTA, 2007, p. 32). Portanto,

um 'programa de pesquisa' constituí-se de um 'núcleo firme'(conjunto de hipóteses ou teoria, considerado como irrefutável pelos cientistas), de uma 'heurística' que instrui os cientistas a modificar o 'cinturão protetor'(conjunto de hipóteses auxiliares e métodos observacionais) de modo a adequar o programa aos fatos (SILVEIRA, 1997, p. 1).

Essa proposta vai ao encontro do que se verifica entre a Semiótica e sua vertente tensiva. A Semiótica Francesa seria, portanto, a superteoria e a Semiótica Tensiva seria uma subteoria que continua dentro do mesmo programa de investigação (aqui usado na acepção de Swiggers (1981)) e com o mesmo objetivo: investigar o sentido. Porém, a heurística seria outra, uma vez que a visão tensiva se utiliza de outros meios para pesquisar as condições de significação.

Todos os programas de pesquisa científica podem ser caracterizados pelo núcleo. A heurística negativa do programa nos proíbe dirigir o modus tollens para esse núcleo. Ao invés disso precisamos utilizar nosso engenho para articular ou mesmo inventar "hipóteses auxiliares" que formam um cinto de proteção em torno do núcleo. (...) É este cinto de proteção e hipóteses auxiliares que tem de suportar o impacto dos testes e ir se ajustando e reajustando (...). (LAKATOS, 1979, p.163)

Por mais que despontem novos modos de se fazer semiótica, como por exemplo, a Semiótica Tensiva, nunca há total rompimento com as concepções inaugurais. Os pressupostos básicos sobre linguagem e sentido continuam os mesmos. Nenhum semioticista da linha francesa vai, por exemplo, negar que, conforme Greimas (1966, p.5) o mundo humano é um mundo essencialmente de significação, ou ainda negar que (p.19) o sentido só se dá na relação de uma "coisa" com outra. Um semioticista desta linha também não negaria a célebre definição de signo de Saussure (2002 [1916], p. 80): "O signo une não uma coisa e uma palavra, mas um conceito e uma imagem acústica", ou seja, um significado e um significante.

É neste sentido que caminham as respostas de Claude Zilberberg na entrevista de 2008, já mencionada.

Com o modelo de Swiggers, pode-se perguntar se, dentro do programa de investigação sociocultural, a semiótica "standard" seria uma teoria e a semiótica tensiva, outra. Entretanto, de acordo com o que analisei e em virtude dos depoimentos dos próprios pesquisadores da semiótica tensiva que sempre afirmam sua ligação com o programa greimasiano, creio que a teoria de Lakatos é a que melhor explica a questão.

\footnotetext{
${ }^{3}$ ALMEIDA, D.; BARROS, M.; LEMOS, C.; MERÇON, F.; ZERBINATTI, B. 2008. Entrevista com Claude Zilberberg, realizado em São Paulo, em agosto de 2008, ainda não publicada.
} 
A emergência dos estudos tensivos não se deu da noite para o dia. Longo foi o caminho percorrido até uma considerável consolidação dos seus conceitos-chave. O marco inicial dos estudos tensivos pode ser considerado o livro Essais sur les modalités tensives (ZILBERBERG, 1981). Em 1988, o autor publica Razão e poética do sentido. As pesquisas permaneceram e em 1998 é publicado o livro Tensão \& Significação, também de Zilberberg, mas desta vez em co-autoria com Jaques Fontanille. Por fim, em 2006 Zilberberg publica Eléments de grammaire tensive, com a consolidação de vários postulados do ponto de vista tensivo.

O quadro comparativo abaixo ajuda a visualizar as principais diferenças entre a semiótica "tradicional" e a "tensiva"

\section{Quadro V: Semiótica "tradicional” vs. "Semiótica Tensiva"}

\begin{tabular}{|c|c|}
\hline $\begin{array}{c}\text { Semiótica greimasiana } \\
\text { "tradicional" }\end{array}$ & Semiótica Tensiva \\
\hline Sujeito do fazer & Sujeito do ser \\
\hline Ênfase ao fazer, agir & $\begin{array}{c}\text { Enfase ao sentir, } \\
\text { perceber }\end{array}$ \\
\hline $\begin{array}{c}\text { Parvenir (lograr, } \\
\text { conseguir fazer algo). }\end{array}$ & $\begin{array}{c}\text { Survenir (súbita } \\
\text { irrupção em meio a um } \\
\text { processo). }\end{array}$ \\
\hline $\begin{array}{c}\text { Programação; } \\
\text { capacidade de } \\
\text { antecipação }\end{array}$ & $\begin{array}{c}\text { Acontecimento (sem } \\
\text { esperar; repentino) }\end{array}$ \\
\hline Lógica da Implicação & Lógica da Concessão \\
\hline $\begin{array}{c}\text { Maior atenção ao nível } \\
\text { narrativo }\end{array}$ & $\begin{array}{c}\text { Maior atenção ao nível } \\
\text { profundo }\end{array}$ \\
\hline
\end{tabular}

\section{A Semiótica Tensiva no Brasil}

\subsection{Os primeiros momentos da recepção e o crescimento da Semiótica Tensiva no Brasil}

Como já dito anteriormente, em 1981 houve a publicação do Livro Essais sur les modalités tensives, de Claude Zilberberg. No depoimento prestado a mim, Luiz Tatit informou que houve notícia do livro no Brasil, mas que muitas pessoas o leram e o deixaram "meio de lado". O professor lembrou também que foi um pouco depois que ocorreu uma visita de Herman Parret ao Brasil (1984) e que ele ministrou, na Universidade de São Paulo, um curso bastante crítico sobre a Semiótica. Neste curso, Parret criticava a herança estrutural que permanecia na Semiótica e clamava por um "amolecimento" da teoria. Segundo Tatit, neste curso Parret falou sobre um pesquisador Francês que tinha propostas interessantes para uma "musicalização" da semiótica. Tal pesquisador era nada menos que Claude Zilberberg. Por esta época, Tatit já estava trabalhando com Semiótica e Música, mais especificamente com a Canção Brasileira. Ele terminara o mestrado em 1982, sob a orientação do professor Cidmar Teodoro Pais ${ }^{4}$ (Sua dissertação se chama Por uma semiótica da canção popular) e

\footnotetext{
${ }^{4}$ Cidmar Pais foi por bastante tempo o coordenador dos cursos de Lingüística da Universidade de São Paulo. "Foi Pais, sem dúvida, quem exerceu as funções intelectuais e, principalmente, organizacionais, necessárias para
} 
estava no meio de seu Doutorado (cuja tese se chama Elementos semióticos para uma tipologia da canção popular brasileira), defendido em 1986, também sob orientação de Pais. A visita de Parret e seus comentários acerca do modelo que Zilberberg propunha chamaram a atenção de Tatit, uma vez que ele enxergou que a concepção tensiva poderia lhe conceder muitos ganhos na descrição de seu objeto, ainda mais porque já havia, também aqui no Brasil, inquietações sobre o modelo semiótico inicial que não era capaz de fornecer algumas respostas.

No depoimento, Tatit comenta que em 1989 algum professor (ele não se lembra exatamente quem) voltou da França e trouxe consigo um exemplar do Raison et poétique du sens de Zilberberg (2006a [1988]). Foi então que ele realmente passou a se interessar pelas propostas zilberberguianas, estudando-as até que escolheu trabalhar com este modelo em sua Tese de Livre Docência, intitulada Semiótica da canção: fundamentos para uma reconstrução do sentido melódico e lingüístico, defendida em 1994. No mesmo ano, houve a publicação do Livro Semiótica da Canção, que pode ser considerado o marco da introdução desta vertente teórica no país. Neste livro, Tatit elabora um modelo para estudar a canção utilizando-se da semiótica. Ele usa, mas não só, conceitos provenientes dos estudos empreendidos por Claude Zilberberg e também explica a proposta de Zilberberg. Porem o professor não utiliza o nome semiótica tensiva, mas simplesmente semiótica ${ }^{5}$. A partir de então, o professor passa a orientar alunos interessados em estudar semiótica e muitos deles pendem para a orientação tensiva, o que passou a caracterizar o professor como o líder intelectual da perspectiva tensiva no Brasil. Basta verificarmos que de todos os trabalhos de Mestrado e Doutorado, realizados na USP, que trazem a Semiótica Tensiva em seus pressupostos, $81 \%$ foi orientado por Tatit. Além disso, em 2003 foi criada a disciplina Semiótica: Teoria e Aplicação na Canção Brasileira, ministrada até hoje e que apresenta, além de outras coisas, propostas da semiótica tensiva.

Muitos dos alunos orientados por Tatit na Pós-graduação tornaram-se professores em Universidades renomadas e continuaram utilizando o esquema tensivo em seus trabalhos. Por exemplo, Ivã Carlos Lopes é docente, ao lado de Tatit, na Universidade de São Paulo; Renata Mancini é docente na Universidade Federal Fluminense, onde coordena o grupo SeDi (Grupo de Pesquisa em Semiótica e Discurso) e "Desenvolve pesquisa sobre o esquematismo tensivo aplicado ao estudo da enunciação de textos sincréticos",; Ana Cristina Fricke Matte, da Universidade Federal de Minas Gerais, entre outros. O fato de ex-alunos tornarem-se professores e continuarem envolvidos com a pesquisa contribui para a manutenção e expansão da teoria.

Desde a publicação de Semiótica da Canção, o aumento do interesse pelas ideias de Zilberberg só cresceu como nos faz perceber a publicação periódica que recolhi para este trabalho. Subiu de $20 \%$ para $37 \%$ o número de artigos "tensivos" publicados no período em questão, nos dois periódicos pesquisados. O gráfico a seguir nos ajuda a visualizar este crescimento.

\footnotetext{
a solidificação institucional da Linguistica - e, mais tarde, da Semiótica - na Universidade de São Paulo" (ALTMAN, 2003, p.112).

${ }^{5}$ Falarei disto mais adiante, na subparte 4.2

${ }^{6}$ Site do grupo SeDi. Disponível em <http://www.uff.br/sedi/pesquisadoresRen.htm>. Acesso em 10/01/2009.
} 


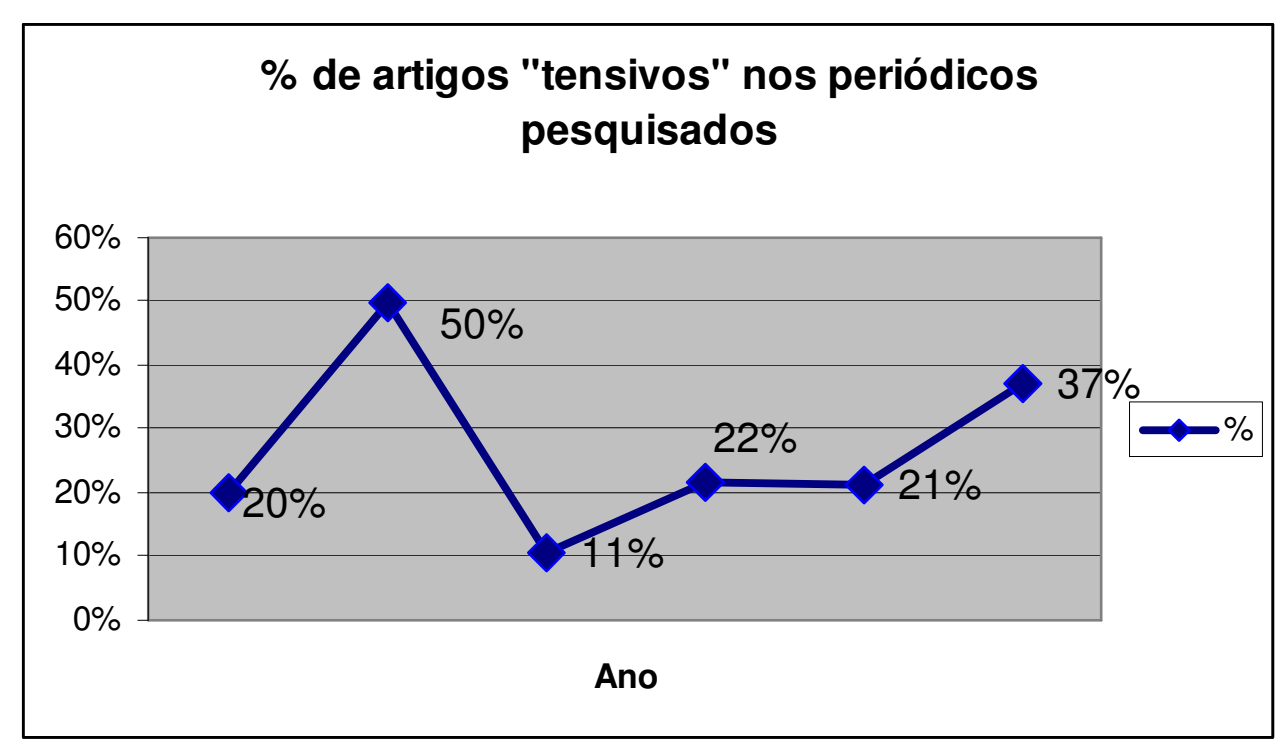

Ademais, não posso deixar de atentar para o fato de já terem ocorrido nestes anos dois cursos ministrados por Zilberberg (sendo que o último deles, de 2008, contou com mais de 100 inscritos), além do curso Elementos de Semiótica Tensiva, ocorrido no primeiro semestre de 2008, promovido pelo Departamento de Linguistica e Serviço de Cultura e Extensão da USP. Para o próximo ano, já está prevista uma semana de palestras proferidas pela professora Renata Mancini, da UFF, sobre o mesmo tema. A escolha de problemas da semiótica tensiva como tema de pesquisa no GT de semiótica da ANPOLL para o próximo biênio (conforme comentei na Introdução) também evidencia a importância e o reconhecimento que tais estudos vêm ganhando nos últimos tempos e, diante dos fatos, não seria exagero dizer que estamos vivendo um boom da semiótica tensiva no âmbito nacional, principalmente em São Paulo e Rio de Janeiro.

Lopes (2009) resume bem a questão em sua entrevista, quando perguntado sobre o início e desenvolvimento da teoria tensiva no Brasil:

Há sempre algo de arbitrário na delimitação desses começos, e é difícil, nessas questões, deixar de cometer alguma injustiça. Desde os anos 1980, alguns pesquisadores brasileiros como a Diana e o Ignácio Assis Silva (UNESP Araraquara) já vinham, aqui e ali, se referindo aos trabalhos de Claude Zilberberg, embora não de maneira sistemática. A tese de LivreDocência do Tatit, que resultaria pouco depois no livro Semiótica da Canção (1994, se estou bem lembrado), é um marco porque ele propõe ali toda uma metodologia de análise da linguagem da canção, baseando-se de forma sistemática na teoria de Zilberberg, tal como se apresentava à época, em uma iniciativa pioneira, internacionalmente falando. A partir desse trabalho, as tentativas anteriores de estudo semiótico da canção acabam soando como tímidos balbucios, como ensaios mais ou menos no escuro. A tese do Tatit mesmo que se trate de um modelo que ele mesmo acabará retificando mais tarde - eleva a discussão a um outro patamar. Pouco depois, em 1997, é o mesmo Tatit quem irá convidar o prof. Zilberberg a ministrar seu primeiro curso no país, na USP. Entre as conseqüências, há uma primeira difusão, amparada pelas publicações dos livros seguintes do Tatit, do esquematismo tensivo, num momento em que Zilberberg, até então solitário nessa empreitada, receberá a contribuição de Jacques Fontanille, outro semioticista 
de grande destaque na França. É a época de publicação de Tension et Signification, cuja versão brasileira sairá em 2001 pela Discurso Editorial / Humanitas e conhecerá uma divulgação razoável. Além disso, os trabalhos do Tatit, e, pouco a pouco, os de alguns orientandos dele também, constituem a primeira demonstração convincente de que a semiótica tensiva tem uma certa operacionalidade prática na análise concreta; sob vários aspectos, era uma demonstração que ainda faltava fazer, e mesmo hoje esse trabalho continua a pedir a nossa atenção.

(Depoimento Pessoal, 2009).

\subsection{Dimensão social: formação de grupos e contato "centro produtor" vs. "centro receptor"}

Neste momento, eu gostaria de fazer algumas considerações sobre a semiótica tensiva no Brasil enquanto grupo de especialidade, seguindo os conceitos de Murray (1994) já brevemente explanados. Lembremo-nos de que, conforme Murray, há quatro estágios no desenvolvimento de um grupo de especialidade. A primeira fase que há pouco descrevi, no início da recepção das ideias tensivas no Brasil, pode ser vista como o estágio "normal", previsto por Murray. Havia poucos pesquisadores e houve um trabalho programático (Semiótica da Canção) que fez emergir a figura de um líder intelectual (Luiz Tatit). A partir daí, é como se os cientistas envolvidos com estas questões estivessem em transição para o cluster. Tentarei explicar essa proposição. Fala-se em Cluster quando os pesquisadores envolvidos com uma teoria tomam consciência de ser parte de um grupo. Isto não é o que ocorre no Brasil, uma vez que não há um grupo que estude exclusivamente Semiótica Tensiva e que se reconheça como tal. Inclusive, os depoimentos nos indicaram que os pesquisadores da área não reivindicam pra si o título de "tensivos", mesmo que seus trabalhos estejam sempre relacionados a esta vertente. Em seu depoimento, Luiz Tatit chega até mesmo a afirmar que ele "nem se interessa muito pelo nome "tensivo" e que para ele o que há é simplesmente Semiótica. Segundo o professor, o embrião dos estudos pendendo para a tensividade já estava presente em Hjelmslev, em Sausurre e em Greimas.

Verifica-se também este mesmo posicionamento numa passagem do livro Analise semiótica através das letras, de 2001 (p. 17):

Adotamos aqui o modelo semiótico (...) considerando especialmente seus desdobramentos no campo das indagações tensivas (...). Isto significa que não dispensamos as notáveis aquisições conceituais do autor de Semântica Estrutural para os níveis narrativo e discursivo do percurso gerativo e nem a eficácia operacional do quadrado semiótico. (grifo nosso)

Na mesma direção vai a resposta de Ivã Lopes quando perguntado se ele acreditava que os pesquisadores envolvidos com a Semiótica Tensiva no Brasil estariam caminhando em direção à formação de um grupo de especialidade diferente do que é o grupo de Semiótica Greimasiana. Ele respondeu:

Não creio, nem é meu desejo que isso venha a se concretizar. Zilberberg, ele mesmo, prefere falar em "ponto de vista tensivo", mais do que em "semiótica tensiva", num gesto de integração e não de ruptura frente às demais pesquisas inspiradas em Greimas (Depoimento Pessoal de Ivã Lopes, 2009). 
Desta forma, vê-se que não há o reconhecimento de um "grupo tensivo". Porém, alguns pesquisadores sempre utilizam este ponto de vista em seus trabalhos, enquanto outros não o fazem, e os estudos mais sérios nesta frente são feitos em alguns centros específicos. Considerando, portanto, estes fatores e os depoimentos colhidos, nota-se que não há uma retórica revolucionária por parte dos pesquisadores, havendo, ao contrário, uma retórica continuísta, o que nos faz pensar neste grupo em formação como um "grupo de elite", nos termos de Murray (1994). Não há periódicos ou eventos especializados em semiótica tensiva, mas pesquisas neste viés se integram a outras instituições já consagradas à Semiótica (como vimos acontecer com os artigos em periódicos e com a definição do tema para o novo biênio da ANPOLL, comentado na Introdução). Então, embora não haja reconhecimento de grupo por parte dos cientistas, é inegável que tem havido um crescimento da disciplina, fazendo com que o grupo não esteja nem na fase normal (pois há várias publicações), nem da de cluster, propriamente dito, mas numa posição intermediaria.

Do ponto de vista da relação com o centro produtor - a França - cabem algumas considerações. Segundo Tatit $\left(\mathrm{DP}^{7}\right)$, os contatos entre Zilberberg e o Brasil começaram certa vez em que a professora Diana Barros foi à França e levou para Zilberberg 0 trabalho que ele terminara havia pouco. Daí, Zilberberg e Tatit passaram a ter um maior contato por meio de cartas (mais tarde, e-mails) e tais contatos se intensificaram com o passar do tempo, com as visitas de Zilberberg ao Brasil e a tradução de seus textos pelo trio Tatit, Lopes e Beividas. Apesar deste contato e do evidente crescimento da "tensividade" no Brasil, parece que não há, por parte dos pesquisadores franceses, muito conhecimento acerca do que realmente se passa por aqui e de qual seria o tamanho de nossa contribuição.

O próprio Zilberberg, cuja trajetória acabou se ligando, de algum modo, ao Brasil nos anos recentes, não parece ter uma ideia das mais claras sobre as nossas pesquisas, o que se comprova na entrevista concedida por ele ao grupo de estudantes uspianos ${ }^{8}$, quando de sua última visita ao país.

(Depoimento Pessoal de Ivã Lopes, 2009).

Outro fato interessante é que, na França, as ideias de Zilberberg, especificamente, tem tido até menos repercussão do que aqui no Brasil. A separação da análise em uma dimensão externa e outra interna talvez ajude a explicar porque a Semiótica Tensiva parece estar recebendo mais atenção no Brasil, seu centro receptor, do que na França, seu centro produtor. Numa dimensão interna, as inquietações que despertaram, no Brasil, os interesses por uma semiótica diferente foram os mesmos que fizeram, na França, certos pesquisadores desenvolverem tal semiótica (estas inquietações ou lacunas já foram elencadas na parte 3). Por outro lado, uma análise da dimensão externa nos revela que, no Brasil, a liderança intelectual que leva a bandeira da tensividade é exercida por pesquisadores que mantém forte vínculo com renomada instituição brasileira, qual seja, a Universidade de São Paulo, ao passo que, na França, essa liderança é exercida pelo fundador da teoria, Claude Zilberberg, que não mantém nenhum vínculo com qualquer instituição Universitária, sendo mais difícil a institucionalização da Semiótica Tensiva como disciplina e atraindo, consequentemente, menos adeptos. No Brasil, os professores mais envolvidos com a Semiótica Tensiva conseguem conquistar alunos dispostos a dar continuidade às pesquisas, o

\footnotetext{
${ }^{7}$ Depoimento Pessoal

${ }^{8}$ ALMEIDA, D.; BARROS, M.; LEMOS, C.; MERÇON, F.; ZERBINATTI, B. 2008. Entrevista com Claude Zilberberg, realizado em São Paulo, em agosto de 2008, ainda não publicada.
} 
que se torna muito difícil quando não se tem um cargo de professor devidamente vinculado a uma instituição de prestígio.

\subsection{Dimensão interna: objetos de pesquisa}

Ao verificar os trabalhos desenvolvidos por aqueles que se ativeram, ainda que timidamente, às propostas da semiótica tensiva, percebe-se que, em sua maior parte, os trabalhos incidem sobre objetos sincréticos (canção, linguagens visuais) e sobre objetos cujo plano da expressão é fundamental na construção do sentido. Ambos os tipos de objeto podem ser mais bem analisados (conforme vimos na parte 3) por uma teoria que considere o contínuo, além de não se ater apenas ao percurso gerativo do sentido, da primeira fase da semiótica greimasiana, que era um modelo apenas para a análise do plano do conteúdo.

\section{Considerações Finais}

A partir da análise realizada, pude concluir que a abordagem tensiva da semiótica greimasiana no Brasil tem conquistado mais e mais pesquisadores ao longo dos anos, seja por motivos relacionados à dimensão interna ou externa à teoria.

Apesar de trazer novas contribuições para o modelo greimasiano e de, muitas vezes, substituir algumas propostas, a semiótica tensiva não constitui um novo paradigma, na acepção kuhniana do termo, e nem é assim vista pelos seus praticantes. Ao contrário, ela é uma "subteoria", uma heurística, parte de uma teoria com um núcleo estabelecido, conforme o modelo de Lakatos.

Mesmo que não formem ainda um cluster, conforme proposta de Murray, os pesquisadores às voltas com a tensividade parecem constituir um 'grupo de elite', com força política e crescimento, mas sem uma retórica de ruptura com a teoria greimasiana dita "standard" e sim com uma retórica de incorporação.

A semiótica tensiva trouxe, neste pouco tempo, muitas contribuições para o cenário brasileiro, permitindo aos pesquisadores o trabalho com fenômenos que não poderiam ser abordados apenas com o instrumental teórico das fases anteriores da Semiótica da Escola de Paris.

\section{Referências Bibliográficas}

ALTMAN, Cristina. A pesquisa lingüística no Brasil (1968-1988). São Paulo: Humanitas/FFLCH/USP, 2003.

BARROS, Diana Luz Pessoa de. Estudos do texto e do discurso no Brasil. D.E.L.T.A.,Vol. 15, Número $\quad$ especial, $1999 . \quad$ Disponível $<$ http://www.scielo.br/pdf/delta/v15nspe/4016.pdf>. Acesso em 10/12/2008.

. Teoria do discurso: fundamentos semióticos. São Paulo: Humanitas, 2001.

Teoria semiótica do texto. São Paulo: Ática, 2003.

BATISTA, Ronaldo de Oliveira. A recepção à Gramática Gerativa no Brasil (1967 1983): um estudo historiográfico. 2007. 189 f. Tese (Doutor em Linguistica) - Faculdade de Filosofia, Letras e Ciências Humanas, Universidade de São Paulo, São Paulo, 2007.

BERTRAND, Denis. Caminhos da semiótica literária. Tradução Grupo CASA. Bauru: EDUSC, 2003.

CADERNOS DE SEMIÓTICA APLICADA. Disponível em $<$ http://www.fclar.unesp.br/seer/index.php?journal=casa $>$. 
ESTUDOS SEMIÓTICOS. Disponível em <http://www.fflch.usp.br/dl/semiotica/es/>. FONTANILLE, Jacques; ZILBERBERG, Claude. Tensão e significação. Trad. Ivã Carlos Lopes; Luiz Tatit; Waldir Beividas. São Paulo: Discurso Editorial/Humanitas, 2001.

GREIMAS, Algirdas Julien Sémantique structurale: recherche de méthode. Paris : Larousse, 1966.

Pour une théorie des modalités. Langages 43, 1976.

Sobre o sentido: ensaios semióticos. Petrópolis: Vozes, 1975.

Du Sens II: essais sémiotiques. Paris: Seuil, 1970.

COURTÉS, Joseph. Dicionário de semiótica. São Paulo: Cultrix, 1983.

Hachette, 1986.

Sémiotique: dictionnaire raisonné de la héorie du langage-II. Paris:

.; FONTANILLE, Jacques. Semiótica das paixões. São Paulo: Ática, 1993.

HJELMSLEV, Louis. Prolegômenos a uma teoria da linguagem. São Paulo: Perspectiva, 1975.

KOERNER, Konrad. Questões que persistem em Historiografia Linguistica. Revista da ANPOLL, Número 2, São Paulo, 1996.

KUHN, THOMAS S. A estrutura das revoluções científicas. Trad. Beatriz Boiera; Nelson Boeira do orig. inglês: The structure os scientific revolutions, 1962. São Paulo: Perspectiva, 2007.

LAKATOS, Imre. O falseamento e a metodologia dos programas de pesquisa científica. In: LAKATOS, Imre; MUSGRAVE, Alan (orgs.). A crítica e o desenvolvimento do conhecimento: quarto volume das atas do Colóquio Internacional sobre Filosofia da Ciência, realizado em Londres em 1965. São Paulo, Cultrix/Ed. da Universidade de São Paulo, 1979.

LOPES, Ivã Carlos; HERNANDES, Nilton (orgs.). Semiótica: objetos e práticas. São Paulo: Contexto, 2005.

MURRAY, Stephen O. Theory groups and the study of language in North America: a social history. Amsterdam: John Benjamins, 1994.

RIBEIRO, Camila dos Santos. A missividade em "Ciao Cadaver", de Delmo Montenegro. Revista Estudos Semióticos, Número 4, São Paulo, 2008. Disponível em $<$ http://www.fflch.usp.br/dl/semiotica/es/eSSe4/2008-eSSe\%5B4\%5D-C.S.RIBEIRO.pdf >. Acesso em 15/12/2008.

SAMPAIO, Cristina. José Luiz Fiorin, Semiótica e Paixão. Eutomia: revista online de Literatura e Linguistica, Ano 1, Número 2, Recife, 2008. Disponível em <http://www.ufpe.br/revistaeutomia/pdfn02/n02artigo4.pdf> Acesso em 15/12/2008.

SAUSSURE, Ferdinand de. Curso de lingüística geral. São Paulo: Cultrix, 2002.

SILVEIRA, Fernando Lang da. A metodologia dos programas de pesquisa: a epistemologia de Imre Lakatos. Caderno Catarinense de Ensino de Física,Vol. 13, Número 3, Florianópolis, 1996. Disponível em < http://www.if.ufrgs.br/ lang/LAKATOS.pdf >. Acesso em 05/01/2009.

SWIGGERS, Pierre. Reflections on (Models for) Linguistic Historiography. In: HÜLLEN (Ed.), 1990.

TATIT, Luiz. Por uma semiótica da canção popular. 2007. 245 f. Dissertação (Mestrado) Faculdade de Filosofia, Letras e Ciências Humanas, Universidade de São Paulo, São Paulo, 1982.

Elementos semióticos para uma tipologia da canção popular brasileira. 1986. 2v. Tese (Doutorado) - Faculdade de Filosofia, Letras e Ciências Humanas, Universidade de São Paulo, São Paulo, 1986. 
CASA, Vol.7 n.2, dezembro de 2009

Tempo e Tensividade na analise da canção. Cadernos de estudo análise musical, nr, 3, São Paulo: Atravez, 1990.

Semiótica da canção: fundamentos para uma construção do sentido melódico e lingüístico. 1994. 367f. Tese (Livre Docência) - Faculdade de Filosofia, Letras e Ciências Humanas, Universidade de São Paulo, São Paulo, 1994.

Semiótica da canção. São Paulo: Escuta, 1994.

Análise semiótica através das letras. São Paulo: Ateliê Editorial, 2001.

ZILBERBERG, Claude. Essai sur les modalités tensives. Amsterdam: Benjamins, 1982.

. Razão e poética do sentido. Trad. Ivã Carlos Lopes; Luiz Tatit; Waldir Beividas.

São Paulo: Edusp, 2006a.

Eléments de grammaire tensive. Limoges: Pulim, 2006b. 